\title{
Effects of polymorphic Robertsonian rearrangements on the frequency and distribution of chiasmata in the water-hyacinth grasshopper, Cornops aquaticum (Orthoptera: Acrididae)
}

\author{
PABLo C. COLOMBO* \\ Laboratorio de Genética, Departamento de Ecología, Genética y Evolución, Facultad de Ciencias Exactas y Naturales, Universidad \\ de Buenos Aires, (1428) Ciudad Universitaria, Buenos Aires, Argentina; e-mail: colombop@ege.fcen.uba.ar
}

Key words. Acrididae, Cornops aquaticum, Robertsonian polymorphisms, recombination, chiasma interference, chiasma distribution

\begin{abstract}
The New World grasshopper Cornops aquaticum (Leptysminae: Acrididae) shows a geographical pattern for three Robertsonian polymorphisms in its southernmost area of distribution in Argentina and Uruguay. The frequency and distribution of chiasmata were analysed in five Argentinian populations. This study reveals a strong redistribution of chiasmata in fusion carriers, with a reduction in proximal and increase of distal chiasma frequency in fusion bivalents and trivalents, when all three karyotypes were compared. However, when only fusion bivalents and trivalents were compared, chiasma frequency was significantly higher in the former than in the latter. This higher chiasma frequency in fusion bivalents is due to an increase in proximal chiasma frequency. It is argued that the reduction in proximal chiasma frequency (relative to unfused bivalents) in fusion bivalents may be due to interference across the centromere. Proximal chiasma reduction in trivalents may be attributed either to a physical effect of structural heterozygosity or to an adaptation to the polymorphic condition. Therefore the differences in the distribution of chiasmata in trivalents and Robertsonian bivalents have different causes.
\end{abstract}

\section{INTRODUCTION}

Robertsonian rearrangements, as well as inversions and whole-arm reciprocal translocations (WARTs), are chromosome rearrangements that may cause a reduction in fertility in structural heterozygotes due to meiotic irregularities, although to a lesser extent than interchanges (Hewitt, 1979). As a matter of fact, heterozygotes for chromosomal rearrangements are less fertile than both homozygotes; as a consequence the heterozygotes are less fit. In this case (subdominance for fitness) selection against heterozygotes leads to the loss of the least frequent karyomorph (Hedrick, 1983). Therefore, the rearrangements would not be expected to be seen in a polymorphic state. However, all the mentioned rearrangements are seen sometimes in polymorphic state as compensatory mechanisms arise that suppress the meiotic irregularities in heterozygotes (e.g., non homologous pairing of mutually inverted sequences of inversion heterozygotes in Trimerotropines and other grasshoppers with pericentric inversions (Colombo \& Confalonieri, 1996), or proximal chiasma suppression in Robertsonian polymorphisms (Bidau, 1990; Colombo, 1990). In the case of Robertsonian translocations the most frequent irregularity in heterozygotes consists of linear orientation in metaphase I, leading to imbalanced gametes. This is most frequent in Robertsonian sub-metacentrics with highly unequal arm length and high chiasma frequency (Baker \& Bickham, 1986; Bidau, 1991; Searle, 1993). This means that acro-telocentric pairs with roughly the same length and low chiasma frequency are preadapted to undergo a Robertsonian change that might lead to a polymorphism, especially if chiasmata are localized distally (Bidau \& Mirol, 1988). However, in some cases the Robertsonian change leads to a reduction in chiasma frequency and distal localization of chiasmata in the rearranged chromosomes, amidst chromosomes on which the frequency and distribution of chiasmata are unrestricted (Colombo, 1993; Bidau, 1990).

In the present paper we examine chiasma position and frequency in the water-hyacinth grasshopper, Cornops aquaticum Bruner (Leptysminae: Acrididae). This New World grasshopper is semi-aquatic and inhabits waterhyacinth, Eichhornia crassipes, upon which it feeds and oviposits (Adis \& Junk, 2003). Early in the 20th century the blue-flowered water-hyacinth E. crassipes was introduced to other continents (mainly Africa) as an ornamental plant. Free of natural enemies, it has become the "World's Worst Water Weed", choking dams, covering lakes and rivers and barring people from free access to water (Centre et al., 2002). Biological control using weevils that feed on water-hyacinth has so far been unsuccessful (Albright et al., 2004). Therefore, C. aquaticum is considered to be a possible biological control agent, and is being widely studied, especially from an ecological point of view. Currently, it is being considered for possible release in South Africa (Oberholzer \& Hill, 2001). It has a wide distribution (from $23^{\circ} \mathrm{N}$ to $35^{\circ} \mathrm{S}$ on the American Continent) (Lhano et al., 2005); in the southernmost part of its distribution a complex system of three

\footnotetext{
* Affiliated to CONICET (Consejo Nacional de Investigaciones Científicas y Técnicas).
} 


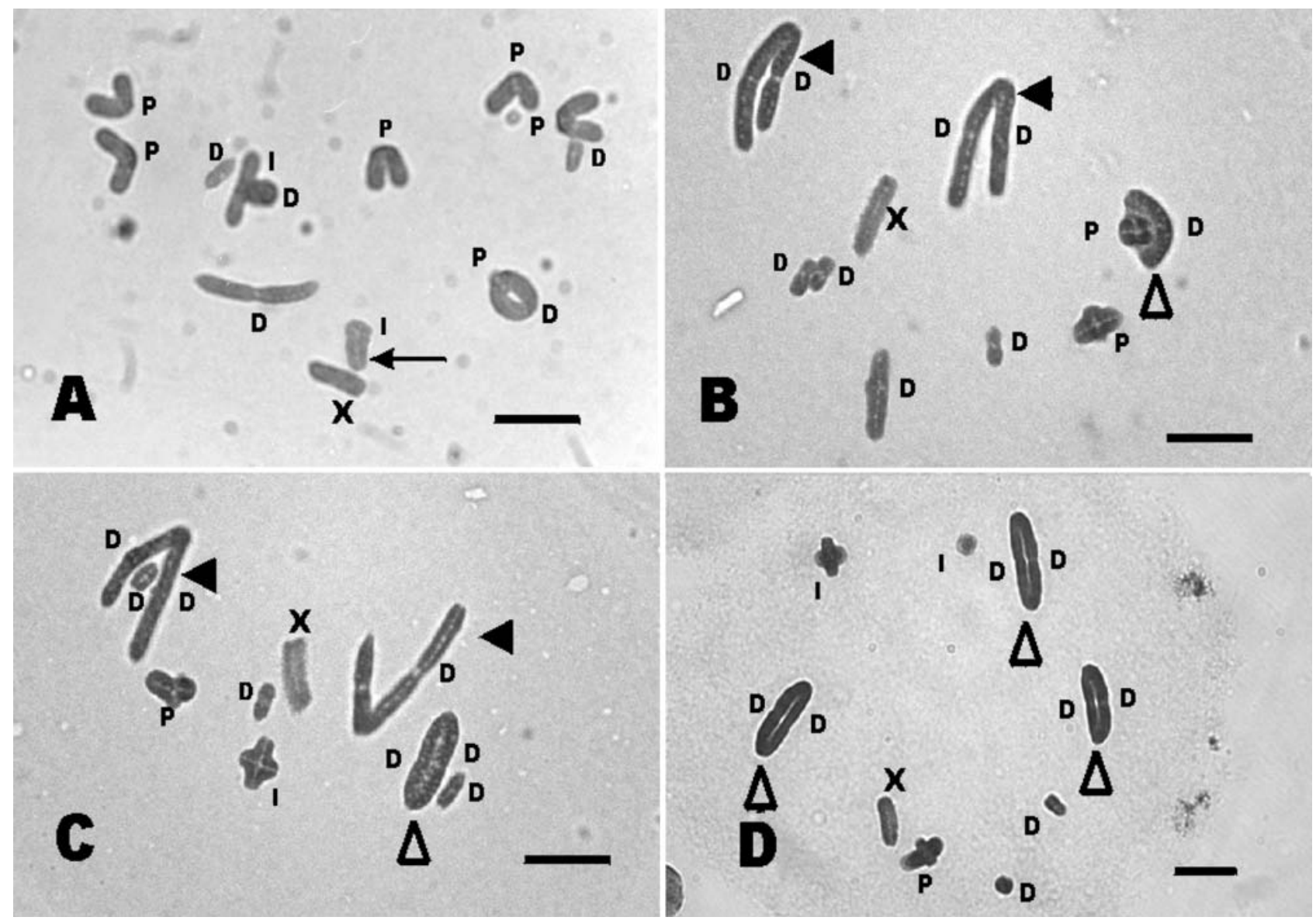

Fig. 1. Metaphase I plates showing chiasma position in different karyotypes of Cornops aquaticum. A. Standard karyotype (no centric fusions), all chromosomes acro/telocentric. Notice the abundance of proximal chiasmata. Arrow: supernumerary segment in the smallest bivalent of the complement. B. Homozygote for one centric fusion and heterozygote for two other fusions. C. Another metaphase I plate from individual B. D. Individual homozygote for all three centric fusions. P - proximal; I - intersitial; D - distal chiasma. Solid arrowhead: Robertsonian trivalent. Outline arrowhead: Robertsonian (meta/submetacentric) bivalent. Bars: $10 \mathrm{~mm}$.

Robertsonian polymorphisms occurs, with the consequent loss of recombination (P.C. Colombo, in prep.); in the rest of South-America it seems to be free of chromosomal polymorphisms. In the present paper, the redistribution of chiasmata triggered by rearrangements is described and interpreted. This redistribution is found both in Robertsonian homozygotes and heterozygotes - but here these are presented as two different cases. Chiasma redistribution in heterozygotes is caused either by a direct effect of the fusion on synapsis or adaptation to the polymorphic condition. In contrast, chiasma redistribution in Robertsonian homozygotes is produced by interference acting across the centromere. In this paper, we test these hypotheses in order to shed light on this problem.

\section{MATERIAL AND METHODS}

In this study, five Argentinian populations were sampled and analysed cytologically. These populations, from north to south, are: Corrientes (20 males), Rosario (8 males), San Pedro (12 males), Zárate (24 males), and Tigre (14 males). Testes were dissected and fixed in 3 ethanol: 1 acetic acid. The cytological analysis was performed by squashing some follicles in proprionic haematoxylin. Male meiosis was studied; chiasmata were registered on 10 metaphase I plates per individual and classified as proximal, interstitial or distal with respect to the centromere.
Although arguably diplotene cells are preferable for chiasma scoring, due to the chromosome condensation at metaphase I, it should be pointed out that diplotene cells are rare in this material, whereas metaphase I cells are abundant, which allows larger samples. Furthermore, it is extremely difficult to see where the centromere lies in diplotene cells, thus rendering it impossible to distinguish between proximal and distal chiasmata. This is especially true of submetacentrics; and last, unlike other material, metaphase I in grasshoppers is a favourable stage for separating chiasmata into proximal, interstitial, and distal (Fig. 1). Chiasma frequencies were recorded as proximal (P), interstitial (I) or distal (D) to the centromere, since there is no need for a more precise chiasma distribution data. Alternative ways of more precisely recording chiasma distribution (such as the "chiasma graph" method, Wada \& Imai, 1995; Imai et al., 1999) may be used in the future, but at this stage of the research the precision afforded by the method employed in this paper is accurate enough for our purposes.

Chiasma frequency and distribution was studied in three groups of chromosomes: (a) acro-telocentric bivalents of unfused homozygotes; (b) trivalents of heterozygotes; (c) metasubmetacentric bivalents of fused homozygotes. Chiasmata were classed as proximal (P), interstitial (I) or distal (D) with respect to the centromere (Table 1).

With the exception of the three small pairs $(9,10$, and 11), which do not take part in the fusions and have generally one distal chiasma, the eight acro-telocentric chromosome pairs 
TABLE 1. Chiasma frequency and distribution in acrocentric bivalents, trivalents and fusion metacentrics. P, I, D, and T - proximal, interstitial, distal, and total chiasmata per acrocentric bivalent, respectively. $\mathrm{P}_{\text {II }}, \mathrm{I}_{\text {II }}, \mathrm{D}_{\text {II }}$, and $\mathrm{T}_{\text {II }}-$ id. per metacentric bivalent. $\mathrm{P}_{\text {III }}, \mathrm{I}_{\text {III }}, \mathrm{D}_{\text {III }}$, and $\mathrm{T}_{\text {III }}-\mathrm{id}$. per trivalent. $\mathrm{N}$ - number of bivalents involved in centric fusions per individuals. The specimens were from Corrientes (C), Zárate (Z), San Pedro (SP), Rosario (R) or Tigre (T).

\begin{tabular}{|c|c|c|c|c|c|c|c|c|c|c|c|c|c|}
\hline Individual & $\mathrm{N}$ & $\mathrm{P}_{\mathrm{II}}$ & $\mathrm{I}_{\mathrm{II}}$ & $\mathrm{D}_{\text {II }}$ & $\mathrm{T}_{\mathrm{II}}$ & $\mathrm{P}_{\text {III }}$ & $\mathrm{I}_{\mathrm{III}}$ & $\mathrm{D}_{\text {III }}$ & $\mathrm{T}_{\mathrm{III}}$ & $\mathrm{P}$ & $\mathrm{I}$ & $\mathrm{D}$ & $\mathrm{T}$ \\
\hline Z05002 & 3 & - & - & - & - & 0.2 & 0.3 & 1.73 & 2.23 & 0.15 & 0.4 & 0.45 & 1.0 \\
\hline Z05004 & 3 & - & - & - & - & 0.2 & 0.3 & 1.6 & 2.1 & 0.7 & 0.15 & 0.15 & 1.0 \\
\hline Z05028 & 2 & 0.9 & 0.1 & 1.8 & 2.8 & 0.2 & 0.4 & 1.5 & 2.1 & 0.77 & 0.17 & 0.3 & 1.23 \\
\hline Z05026 & 3 & 1.16 & 0.33 & 1.0 & 2.5 & 1.16 & 0.5 & 1.66 & 2.33 & 0.92 & 0 & 0.08 & 1 \\
\hline Z05012 & 3 & 0.2 & 0.2 & 1.7 & 2.1 & 0.05 & 0.55 & 1.45 & 2.05 & 0.7 & 0.05 & 0.3 & 1.05 \\
\hline Z05007 & 3 & 0.05 & 0.65 & 1.6 & 2.3 & 0.1 & 0.1 & 2.0 & 2.2 & 0.5 & 0.05 & 0.45 & 1.0 \\
\hline Z05005 & 2 & - & - & - & - & 0 & 0.7 & 1.75 & 2.45 & 0.33 & 0.3 & 0.55 & 1.1 \\
\hline $\mathrm{Z} 05020$ & 3 & - & - & - & - & 0.3 & 0.73 & 1.33 & 2.36 & 0.9 & 0.05 & 0.05 & 1.0 \\
\hline Z05011 & 2 & - & - & - & - & 0.25 & 0.25 & 1.7 & 2,2 & 0.25 & 0.2 & 0.73 & 1.18 \\
\hline Z05014 & 3 & 0.33 & 0.33 & 1.88 & 2.55 & 0.11 & 0.33 & 1.66 & 2.11 & 0.66 & 0.22 & 0.28 & 1.16 \\
\hline Z05024 & 2 & - & - & - & - & 0.05 & 0 & 1.95 & 2 & 0.45 & 0.18 & 0.5 & 1.13 \\
\hline Z05023 & 1 & 0.3 & 0.3 & 1.5 & 2.1 & - & - & - & - & 0.5 & 0.27 & 0.26 & 1.03 \\
\hline Z05008 & 3 & 0.4 & 0.3 & 1.9 & 2.6 & 0.2 & 0.6 & 1.45 & 2.25 & 0.75 & 0.1 & 0.15 & 1.0 \\
\hline Z05010 & 2 & 0.3 & 0.8 & 1.2 & 2.3 & 0.3 & 0.5 & 1.6 & 2.4 & 0.55 & 0.18 & 0.45 & 1.18 \\
\hline Z05021 & 2 & 0.3 & 0.6 & 1.8 & 2.7 & 0.4 & 0.6 & 1.4 & 2.4 & 0.63 & 0.18 & 0.42 & 1.23 \\
\hline Z05006 & 3 & 0.2 & 0.55 & 1.5 & 2.25 & 0 & 0.7 & 1.3 & 2.0 & 0.5 & 0 & 0.5 & 1.0 \\
\hline Z05027 & 2 & - & - & - & - & 0.2 & 0.15 & 1.95 & 2.3 & 0.35 & 0.38 & 0.4 & 1.13 \\
\hline Z05025 & 2 & 0.5 & 0.1 & 1.8 & 2.4 & - & - & - & - & 0.5 & 0.3 & 0.27 & 1.07 \\
\hline Z05013 & 2 & - & - & - & - & 0.15 & 1.0 & 1.35 & 2.5 & 0.09 & 0.05 & 0.3 & 1.25 \\
\hline Z05015 & 3 & 0.5 & 0.9 & 1.5 & 2.9 & 0.8 & 0.4 & 1.4 & 2.6 & 0.25 & 0.25 & 0.6 & 1.1 \\
\hline Z05009 & 1 & - & - & - & - & 0.2 & 0.6 & 1.6 & 2.4 & 0.45 & 0.3 & 0.47 & 1.22 \\
\hline Z05016 & 2 & - & - & - & - & 0.25 & 0.7 & 1.15 & 2.1 & 0.55 & 0.33 & 0.38 & 1.26 \\
\hline Z05029 & 2 & 0.7 & 0.3 & 1.1 & 2.1 & 0.2 & 0.6 & 1.4 & 2.2 & 0.5 & 0.3 & 0.35 & 2.3 \\
\hline Z05022 & 3 & 0.05 & 0.05 & 1.94 & 2.11 & 0 & 0.11 & 2.0 & 2.11 & 0.84 & 0.01 & 0.4 & 1.25 \\
\hline SP05001 & 1 & - & - & - & - & 0.3 & 0.4 & 1.6 & 2.3 & 0.58 & 0.15 & 0.53 & 1.26 \\
\hline SP05002 & 0 & - & - & - & - & - & - & - & - & 0.74 & 0.11 & 0.44 & 1.29 \\
\hline SP05003 & 2 & - & - & - & - & 0.05 & 0.45 & 1.5 & 2.0 & 0.78 & 0.07 & 0.43 & 1.28 \\
\hline SP05004 & 2 & - & - & - & - & 0.05 & 0.25 & 1.8 & 2.1 & 0.48 & 0.17 & 0.4 & 1.05 \\
\hline SP05005 & 2 & - & - & - & - & 0.1 & 0.2 & 2.0 & 2.3 & 0.8 & 0.18 & 0.27 & 1.25 \\
\hline SP05006 & 2 & 0.3 & 0.9 & 0.9 & 2.0 & 0 & 0 & 2.0 & 2.0 & 0.85 & 0 & 0.35 & 1.2 \\
\hline SP05007 & 1 & - & - & - & - & 0.1 & 0.1 & 1.8 & 2.0 & 0.43 & 0.25 & 0.38 & 1.06 \\
\hline SP05008 & 2 & 0.5 & 0.63 & 1.75 & 2.88 & 0 & 0.38 & 1.75 & 2.13 & 0.63 & 0.07 & 0.55 & 1.25 \\
\hline SP05009 & 1 & - & - & - & - & 0.6 & 0.4 & 1.2 & 2.2 & 0.72 & 0.04 & 0.65 & 1.41 \\
\hline SP05010 & 0 & - & - & - & - & - & - & - & - & 0.63 & 0.2 & 0.64 & 1.47 \\
\hline SP05011 & 1 & - & - & - & - & 0.4 & 0.8 & 1.4 & 2.6 & 0.74 & 0.13 & 0.48 & 1.35 \\
\hline R05007 & 0 & - & - & - & - & - & - & - & - & 0.6 & 0.2 & 0.63 & 1.43 \\
\hline R05004 & 0 & - & - & - & - & - & - & - & - & 0.57 & 0.09 & 0.5 & 1.16 \\
\hline R05006 & 0 & - & - & - & - & - & - & - & - & 0.47 & 0.1 & 0.56 & 1.13 \\
\hline R05012 & 1 & - & - & - & - & 0.2 & 0.3 & 1.9 & 2.4 & 0.8 & 0.12 & 0.38 & 1.3 \\
\hline R05010 & 0 & - & - & - & - & - & - & - & - & 0.45 & 0.2 & 0.66 & 1.31 \\
\hline R05015 & 0 & - & - & - & - & - & - & - & - & 0.67 & 0.4 & 0.59 & 1.66 \\
\hline R05013 & 0 & - & - & - & - & - & - & - & - & 0.58 & 0.09 & 0.72 & 1.39 \\
\hline R05011 & 0 & - & - & - & - & - & - & - & - & 0.78 & 0.12 & 0.45 & 1.35 \\
\hline T05015 & 3 & 0.3 & 0.17 & 1.83 & 2.6 & - & - & - & - & 0.6 & 0.1 & 0.3 & 1.0 \\
\hline T05011 & 3 & 0.07 & 0.1 & 1.97 & 2.3 & - & - & - & - & 0.85 & 0.15 & 0 & 1.0 \\
\hline T05014 & 3 & 0.25 & 0.13 & 1.88 & 2.8 & 0.0 & 0.25 & 1.75 & 2.0 & 0.77 & 0.17 & 0.3 & 1.24 \\
\hline T05021 & 3 & 1.14 & 0.42 & 1.44 & 3.0 & 0.19 & 0.19 & 1.68 & 2.06 & 0.92 & 0 & 0.08 & 1.0 \\
\hline Т05017 & 3 & 0.33 & 0.33 & 1.66 & 2.33 & 0.17 & 0.0 & 1.83 & 2.0 & 0.7 & 0.05 & 0.3 & 1.05 \\
\hline T05012 & 2 & - & - & - & - & 0.0 & 0.67 & 1.83 & 2.2 & 0.75 & 0.15 & 0.5 & 1.4 \\
\hline Т05013 & 3 & 0.0 & 0.0 & 2.0 & 2.0 & 0.0 & 0.66 & 1.66 & 2.33 & 0.16 & 0.0 & 0.84 & 1.0 \\
\hline C05039 & 0 & - & - & - & - & - & - & - & - & 0.63 & 0.26 & 0.46 & 1.35 \\
\hline $\mathrm{C} 05002$ & 0 & - & - & - & - & - & - & - & - & 0.64 & 0.29 & 0.35 & 1.28 \\
\hline $\mathrm{C} 05035$ & 0 & - & - & - & - & - & - & - & - & 0.69 & 0.11 & 0.44 & 1.24 \\
\hline $\mathrm{C} 05046$ & 0 & - & - & - & - & - & - & - & - & 0.52 & 0.27 & 0.44 & 1.23 \\
\hline $\mathrm{C} 05020$ & 0 & - & - & - & - & - & - & - & - & 0.73 & 0.17 & 0.36 & 1.26 \\
\hline $\mathrm{C} 05032$ & 0 & - & - & - & - & - & - & - & - & 0.69 & 0.16 & 1.73 & 1.58 \\
\hline $\mathrm{C} 05041$ & 0 & - & - & - & - & - & - & - & - & 0.73 & 0.07 & 0.55 & 1.35 \\
\hline $\mathrm{C} 05012$ & 0 & - & - & - & - & - & - & - & - & 0.88 & 0.12 & 0.45 & 1.45 \\
\hline $\mathrm{C} 05030$ & 0 & - & - & - & - & - & - & - & - & 0.59 & 0.16 & 0.5 & 1.25 \\
\hline $\mathrm{C} 05004$ & 0 & - & - & - & - & - & - & - & - & 0.71 & 0.19 & 0.35 & 1.25 \\
\hline $\mathrm{C} 05021$ & 0 & - & - & - & - & - & - & - & - & 0.89 & 0.11 & 0.41 & 1.41 \\
\hline $\mathrm{C} 05005$ & 0 & - & - & - & - & - & - & - & - & 0.78 & 0.05 & 0.5 & 1.33 \\
\hline $\mathrm{C} 05033$ & 0 & - & - & - & - & - & - & - & - & 0.67 & 0.17 & 0.44 & 1.28 \\
\hline $\mathrm{C} 05006$ & 0 & - & - & - & - & - & - & - & - & 0.58 & 0.34 & 0.55 & 1.47 \\
\hline $\mathrm{C} 05044$ & 0 & - & - & - & - & - & - & - & - & 0.68 & 0.21 & 0.46 & 1.35 \\
\hline $\mathrm{C} 05025$ & 0 & - & - & - & - & - & - & - & - & 0.83 & 0.13 & 0.52 & 1.48 \\
\hline C05019 & 0 & - & - & - & - & - & - & - & - & 0.62 & 0.12 & 0.33 & 1.07 \\
\hline $\mathrm{C} 05040$ & 0 & - & - & - & - & - & - & - & - & 0.63 & 0.26 & 0.37 & 1.26 \\
\hline $\mathrm{C} 05003$ & 0 & - & - & - & - & - & - & - & - & 0.48 & 0.37 & 0.42 & 1.27 \\
\hline $\mathrm{C} 05029$ & 0 & - & - & - & - & - & - & - & - & 0.66 & 0.26 & 0.42 & 1.34 \\
\hline
\end{tabular}




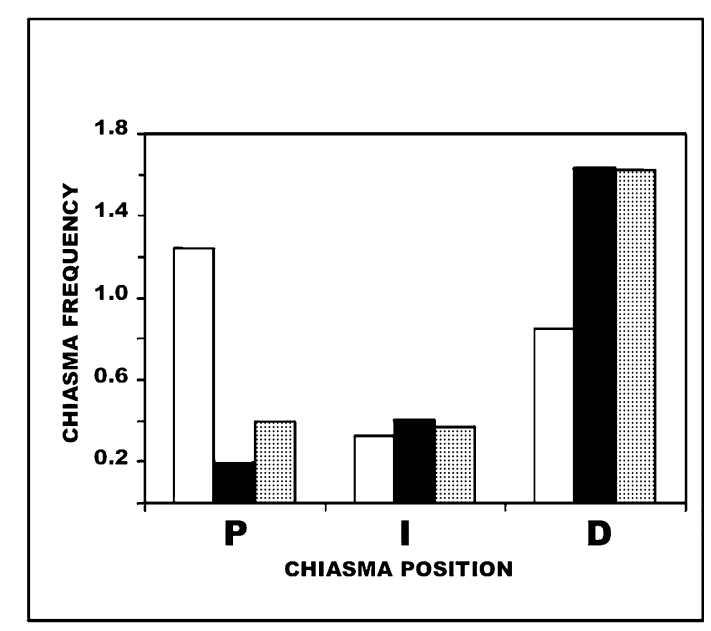

Fig. 2. Histograms showing chiasma frequency in: $\mathrm{P}-$ proximal, I - interstitial, and D - distal positions for acro/telocentric bivalents (white columns), Robertsonian trivalents (dark grey columns), and Robertsonian bivalents (light grey columns).

cannot be differentiated from each other. For example, in an individual that is heterozygous for a single centric fusion, there are six acro-telocentric bivalents that could take part in the fusions. Let $b$ be the number of bivalents of non-fused chromosomes; the mean number of proximal chiasmata would be the sum of proximal chiasmata on all these bivalents divided by $b$. In the case of trivalents, this figure was calculated as the quotient between the sum of all proximal chiasmata on trivalents and the number of trivalents. The same rationale was used for fusion bivalents.

The results for the specimens from Corrientes, for which there are no centric fusions, Rosario, which have a very low fusion frequency, San Pedro and Zárate, which are highly polymorphic, and Tigre, which have a very high fusion frequency, were analysed by means of a MANOVA performed with karyotype (unfused bivalents, trivalents or fusion bivalents) and population type $(1=$ no centric fusions, $2=$ very low fusion frequency, $3=$ highly polymorphic I, $4=$ highly polymorphic II, and $5=$ very high fusion frequency) as grouping variables, and $\mathrm{P}, \mathrm{I}$, and $\mathrm{D}$ as dependent variables. T was assessed by means of a separate ANOVA. In the following analyses $\mathrm{P}, \mathrm{I}, \mathrm{D}$, and T chiasma frequencies of unfused bivalents were multiplied by two, in order to render them comparable with trivalent and Robertsonian bivalent chiasma frequencies. Data were processed using the STATISTICA package.

\section{RESULTS}

MANOVA revealed that there is a highly significant reduction of proximal chiasma frequency and a highly significant increase of distal chiasma frequency in fusion bearers (Wilks' Lambda $=0.3216, P<0.000001$ ) (Fig. $2)$. If the individual analyses of variance are taken into account, it is evident that there is a reduction of proximal chiasma frequency and an increase of distal chiasma frequency in fusion carriers (Table 2) (Fig. 2). The effects of the factor "population" were not significant, with the exception of D $(P=0.014)$. Thus so far the effects of the Robertsonian changes are as expected, reduction in proximal and increase in distal chiasma frequency. However, if the two types of fusion carriers are compared, i.e. fusion homozygotes and heterozygotes, by means of

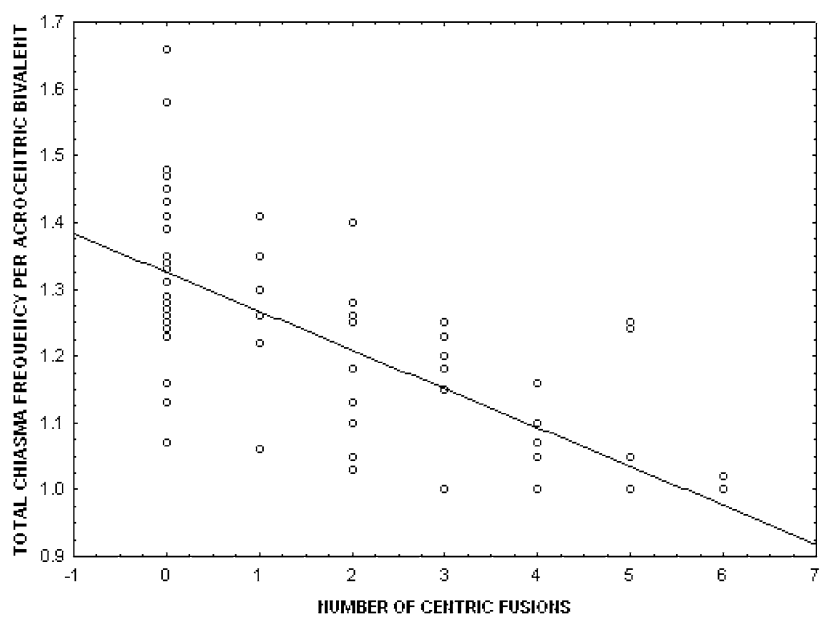

Fig. 3. Scatterplot and regression line of total chiasma frequency in acro/telocentric bivalents per bivalent $(\mathrm{Y})$ on number of centric fusions per individual (X).

Fisher's least significant difference (Fisher LSD) contrasts, then the proximal chiasma frequency decreases in trivalents and Robertsonian bivalents relative to standard bivalents $(P<0.00001$ in both cases), but there are significant differences between fusion bivalents and trivalents $(P=0.0277)$ (Table 2 , Fig. 2$)$; with the trivalents having a significantly lower frequency of proximal chiasmata than fused bivalents. This again points to the fact that the effect of centric fusions on chiasma frequency is different in fused bivalents and trivalents. There is no difference between fusion bivalents and trivalents in distal chiasma frequency $(P=0.2584)$.

In summary, proximal chiasma frequency is lower in trivalents than unfused bivalents, but it rises again slightly in fusion bivalents. Likewise, distal chiasma frequency is low in both fusion bivalents and trivalents, with no difference between these two karyotypes. As a consequence of this redistribution, total chiasma frequency remains unchanged.

\section{Interchromosomal effects}

In order to detect an effect of Robertsonian translocations on the frequency and position of chiasmata on the pairs of chromosomes that are not affected by the rearrangements, individual regressions between $\mathrm{P}, \mathrm{I}, \mathrm{D}$, and $\mathrm{T}$, and the variable "number of centric fusions per individual" were performed. The regression was negative and highly significant for T $(P<0.0000001)$ (Table 3, Fig. 3). That for $\mathrm{D}$ and I were also significant $(P=0.000095$ and $P=0.015524$, respectively). Otherwise, the total number of chiasmata decreases with increase in number of centric fusions; this is explained mostly by a decrease in distal and, to a lesser extent, interstitial chiasmata. Hence, the interchromosome effects appear to differ from the intrachromosome effects (which mainly consist of a decrease in proximal and an increase of distal chiasmata, while the total number of chiasmata remains constant). 
TABLE 2. MANOVA comparing chiasma frequency and position in different karyotypes of Cornops aquaticum. R IIs - Robertsonian bivalents; IIIs - trivalents; S IIs - standard bivalents; $\mathrm{P}$ - proximal; I - interstitial; D - distal; T - total number of chiasmata. ** - highly significant; * - significant; ns - not significant.

\begin{tabular}{lccccc}
\hline \multicolumn{7}{l}{ (a) ANOVA of total chiasmata. } \\
\hline \multicolumn{1}{c}{ SS } & DF & MS & F & p \\
\hline Intercept & 590.169 & 1 & 590.1689 & 7.624245 & 0.006649 \\
Karyotype & 144.010 & 2 & 72.0051 & 0.930216 & 0.397248 \\
Population & 60.674 & 4 & 15.1685 & 0.195958 & 0.940089 \\
Error & 9443.637 & 122 & 77.4069 & & \\
\hline
\end{tabular}

(b) Mean values. Wilk's lambda $=0.3216, P<0.00001$.

\begin{tabular}{ccccc}
\hline & $\mathrm{P}$ & $\mathrm{I}$ & $\mathrm{D}$ & $\mathrm{T}$ \\
\hline RIIs & 0.399091 & 0.371864 & 1.615680 & 2.389545 \\
IIIs & 0.178500 & 0.399158 & 1.637860 & 2.216000 \\
SIIs & 1.236480 & 0.339676 & 0.863985 & 2.443470 \\
\hline
\end{tabular}

(c) Separate analysis of variance for each variable.

\begin{tabular}{cccc}
\hline & Mean Sqr Effect & $\begin{array}{c}F(\mathrm{df} 1,2) \\
2,125\end{array}$ & $P$-level \\
\hline $\mathrm{P}$ & 10.3758 & 175.640 & $0.000000^{* *}$ \\
$\mathrm{I}$ & 0.0799 & 1.5217 & $0.2224 \mathrm{~ns}$ \\
$\mathrm{D}$ & 9.2143 & 70.1110 & $0.000000^{* *}$ \\
\hline
\end{tabular}

(d) Fisher's LSD contrasts for unequal $\mathrm{N}$ for proximal chiasmata.

\begin{tabular}{cccc}
\hline & R IIs & IIIs & S IIs \\
\hline Avg. value & 0.399090 & 0.178500 & 1.236485 \\
R Iis & & $0.027783^{*}$ & $<.0000001^{* *}$ \\
IIIs & & & $<.0000001^{* *}$ \\
\hline
\end{tabular}

In future, more precise studies of chiasma distribution, like those in Leptysma argentina (Colombo, 1993) will be undertaken. An alternative method of describing the distribution of chiasmata was put forward by Wada \& Imai (1995) and Imai et al. (1999) (called the "chiasma graph" method) and a detailed analysis of their methodology may enrich the approach to the study of chiasma distribution in Cornops aquaticum, a study which, in addition to its cytological importance, has obvious evolutionary implications.

\section{DISCUSSION}

It is recognized that, whenever Robertsonian rearrangements are found in a polymorphic state, the chiasma frequency in trivalents is remarkably reduced, in particular the proximal chiasma frequency (Colombo, 1989, 1990, 1993; Bidau, 1990; Bidau \& Martí, 2005; Hewitt \& Schroeter, 1968). It is suggested that this reduction is normally caused by an adaptation to the polymorphic situation, and is adaptive for the species (Colombo, 1989, 1993). Alternatively, it is proposed that the suppression of proximal chiasmata in the trivalents of heterozygotes is due to a direct effect of delayed synapsis in the trivalents (Bidau \& Martí, 2002; Davisson \& Akeson, 1993). How-
TABLE 3. Regression of proximal, interstitial, distal, and total chiasma frequency of acrocentric bivalents (per bivalent) (P, I, $\mathrm{D}$, and $\mathrm{T}$, respectively) on the variable number of Robertsonian rearrangements per individual.

\begin{tabular}{cccc}
\hline & $\mathrm{B}$ & $\mathrm{t}(68)$ & $\mathrm{p}$-level \\
\hline $\mathrm{P}$ & -0.37884 & -0.31238 & 0.755703 \\
$\mathrm{I}$ & -5.12752 & -2.48241 & $0.015524^{*}$ \\
$\mathrm{D}$ & -5.16232 & -4.14813 & $0.000095^{* *}$ \\
$\mathrm{~T}$ & -8.13918 & -7.85562 & $0.000000^{* * *}$ \\
\hline
\end{tabular}

ever, all the reported cases of Robertsonian heterozygosity causing proximal chiasma suppression are for Robertsonian polymorphisms.

The European house mouse (Mus musculus domesticus) is an excellent model for this type of study, as they are easily reared in laboratory conditions, can be crossed experimentally, and both cytological and genetic studies can be performed with ease; furthermore, they are polymorphic and/or polytypic for several Robertsonian rearrangements (Garagna et al., 2001). Studies on this species are consistent in showing that both chiasma conditions and genetic recombination are affected by Robertsonian rearrangements, which results in a decrease in the number of chiasmata in proximal regions (Davisson \& Akeson, 1993; Dumas \& Britton-Davidian, 2002; Bidau et al., 2001; Bidau \& Martí, 2005). However, the study of Dumas \& Britton-Davidian (2002) deals only with fusion and acrocentric homozygotes. They compared two populations that differ in several Robertsonian rearrangements. When hybrids between Robertsonian races of mice are analysed, the proximal and interstitial chiasma frequencies increase, rather than decrease, in the trivalents of heterozygotes (Bidau et al., 2001). Unfortunately, it is unclear whether the Robertsonian heterozygotes (which do show proximal chiasma frequency reduction) studied by Davisson and Akeson (1993) were obtained from polymorphic or polytypic populations. Furthermore, it is claimed, at least in some cases, that a partial asynapsis or rather a delay in pairing is correlated with proximal chiasma suppression (Bidau \& Martí, 2002; Davisson \& Akeson, 1993). However, it is unclear in what direction the arrow of causation should point. Is asynapsis a cause of the proximal chiasma suppression, or a consequence? In species with strict chiasma localisation, it is accompanied by asynapsis, though in these cases no structural hybridity is impeding synapsis (Del Cerro et al., 1997; Fletcher, 1977). What we predict is that generally, when proximal chiasma suppression in Robertsonian trivalents is observed, it will be in heterozygotes of Robertsonian polymorphisms, rather than hybrids (natural or otherwise) between different chromosomal races. This can be easily falsified by testing chiasma distribution in hybrid mice.

However, a general feature of the meiosis of polytypic or polymorphic Robertsonian heterozygotes is that fusion bivalents also show a more distal redistribution of chiasmata, although in this case the change is not necessary for the maintenance of the polymorphism. This change is not as marked as in heterozygotes (at least in Robertsonian 
polymorphisms). This change is different from that observed in trivalents (Bidau, 1990; Colombo, 1993; Bidau et al., 2001, Bidau \& Martí, 2005; this paper) and is also present in fusion homozygotes even though the trivalents of heterozygotes do not show proximal chiasma suppression (Bidau et al., 2001). We know that interference can act through the centromere. In a previous paper (Colombo \& Jones, 1997) we demonstrate that in the grasshoppers Leptysma argentina and Chorthippus brunneus interference does act across the centromere, contrary to the general belief, which can be traced back to Mather (1938). Broman \& Weber (2000) studied on human meiosis, and also found that interference was "blind" to centromeres. Hence we propose that the chiasma redistribution found in Robertsonian bivalents is due to the action of interference across the centromere. This cannot be the case in trivalents given that interference and a complete synaptonemal complex are usually connected (Sym \& Roeder, 1994). Recently it was argued that this correlation does not reflect causation -at least in the traditional view. Rather, it is proposed that SC formation might need the action of interference (Börner et al., 2004). Anyway, the two phenomena go together. Henceforth, we also predict that, when chiasma redistribution is seen in Robertsonian bivalents and trivalents, it is of a different nature because of a different cause.

The interchromosomal effects are remarkable as they differ from the intrachromosomal effects. In the former, the total number of chiasmata decrease as a result of centric fusions; this is due to a decrease in the distal and, to a lesser extent, interstitial chiasma frequencies, with the proximal chiasma frequency remaining unchanged. In the latter, by contrast, proximal chiasma frequency decreases and distal chiasma frequency increases with increasing fusion numbers, and the proximal chiasma frequency remains unchanged. In Leptysma argentina (Colombo, 1990), a polymorphic centric fusion result in interchromosomal effects addition to the intrachromosomal effects; both, however, result in an overall decrease in the total and proximal chiasmata. Intrachromosomal effects, as mentioned, are necessary for the maintenance of polymorphisms; interchromosomal ones, by contrast, are most likely side effects of this type of rearrangement and its cytological basis is still unknown.

ACKNOWLEDGEMENTS. The author wishes to thank $\mathrm{S}$ Maris Marques from the Club Náutico de Zárate, F. Suárez from the Club Náutico de San Pedro, the Club de Regatas Rosario, M.C. Franceschini from the CECOAL, Corrientes, and S. Copello and M. Marchese from the INALI, Santa Fe, for the facilities afforded to the author for the capture of the specimens. I also wish to thank G.H. Jones for critical reading this paper and useful comments, an anonymous reviewer of EJE whose suggestions substantially improved the manuscript and C.J. Bidau for suggesting, several years ago, that Cornops aquaticum was an excellent animal to work with. Funding provided by Universidad de Buenos Aires (X-309/04) through grants to M.I. Remis is gratefully acknowledged.

\section{REFERENCES}

Adis J. \& JunK W. 2003: Feeding impact and bionomics of the grasshopper Cornops aquaticum on the waterhyacinth Eichhornia crassipes in Central Amazonian floodplains. Stud. Neotrop. Fauna Environ. 38: 245-249.

Albright T., Moorhouse T. \& McNabB T. 2004: The rise and fall of water hyacinth in Lake Victoria and the Kagera river basin, 1989-2001. J. Aquat. Plant Manag. 42: 73-84.

BAKER R. \& BicKHAM J. 1986: Speciation by monobrachial centric fusions. Proc. Nat. Acad. Sci. USA 83: 8245-8248.

BiDAU C. 1990: The complex Robertsonian system of Dichroplus pratensis (Melanoplinae: Acrididae). II. Effects of the fusion polymorphisms on chiasma frequency and distribution. Heredity 64: 145-159.

BIDAU C. 1991: Multivalents resulting from monobrachial homologies within a hybrid zone in Dichroplus pratensis (Acrididae): meiotic orientation and segregation. Heredity 66: 219-232.

Bidau C. \& Martí D. 2002: Geographic distribution of Robertsonian fusions in Dichroplus pratensis (Melanoplinae, Acrididae): the central-marginal hypothesis reanalysed. Cytogenet. Genome Res. 96: 66-74

Bidau C. \& Martí D. 2005: Variability along a latitudinal gradient in the chiasma frequency and morphological characters of Dichroplus pratensis (Orthoptera: Acrididae). Eur. J. Entomol. 102: 1-12.

BIDAU C. \& MiROL P. 1988: Orientation and segregation of Robertsonian trivalents in Dichroplus pratensis (Acrididae). Genome 30: 947-955.

Bidau C., Giménez M., Palmer C. \& Searle J. 2001: The effects of Robertsonian fusions on chiasma frequency and distribution in the house mouse (Mus musculus domesticus) from a hybrid zone in northern Scotland. Heredity 87: 305-313.

Broman K. \& Weber J. 2000: Characterization of Human Crossover interference. Am. J. Hum. Genet. 66: 1911-1926.

BöRner G.V., KLECKNER N. \& Hunter N. 2004: Crossover/noncrossover differentiation, synaptonemal complex formation, and regulatory surveillance at the leptotene/zygotene transition of meiosis. Cell 117: 29-45

Centre T., Hill M., Cordo H. \& Julien M. 2002: Waterhyacinth. In Van Driesche R. et al. (eds): Biological Control of Invasive Plants in the Eastern United States. USDA Forest Service Publications, Morgantown, $413 \mathrm{pp}$.

Colombo P. 1989: Chromosome polymorphisms affecting recombination and exophenotypic traits in Leptysma argentina (Orthoptera): a populational survey. Heredity 62: 289-299.

Colombo P. 1990: Effects of centric fusions on chiasma frequency and position in Leptysma argentina (Acrididae: Orthoptera). II. Intra- and interchromosome effects. Caryologia 43: 131-147.

Colombo P. 1992: A new index for estimating genetic recombination from chiasma distribution data. Heredity 69: 412-415.

Colombo P. 1993: A polymorphic centric fusion enhances chiasma interference in a grasshopper; a chiasma distribution approach. Heredity 70: 254-265.

Colombo P. \& Confalonieri V. 1996: Adaptive pattern of inversion polymorphism in Trimerotropis pallidipennis. Correlation with environmental variables: an overall view. Hereditas 125: 289-296.

Colombo P. \& Jones G. 1997: Chiasma interference is blind to centromeres. Heredity 79: 214-227.

DAVISSON M. \& AKeson E. 1993: Recombination suppression by heterozygous Robertsonian chromosomes in the mouse. Genetics 133: 649-667. 
Del Cerro A., Jones G. \& Santos J. 1997: Chiasma localization and incomplete synapsis in two species of Tetrigidae (Orthoptera). Chromosome Res. 5: 69-71.

Dumas D. \& Britton-Davidian J. 2002: Chromosomal rearrangements and evolution of recombination: comparison of chiasma distribution patterns in standard and Robertsonian populations of the house mouse. Genetics 162: 1355-1366.

FLETCHER H. 1977: Localised chiasmata due to partial pairing: a $3 \mathrm{D}$ reconstruction of synaptonemal complexes in male Stethophyma grossum. Chromosoma 65: 247-269.

Garagna S., Marziliano N., Zuccotti M., Searle J., Capanna E. \& REDI C. 2001: Pericentromeric organization at the fusion point of mouse Robertsonian translocation chromosomes. Proc. Natl. Acad. Sci. USA 98: 171-175.

HedRICK F. 1983: Genetics of Populations. Jones \& Bartlett, Boston, MA, $629 \mathrm{pp}$.

Hewitt G. 1979: Animal Cytogenetics Vol. 3, Insecta. 1. Orthoptera. Gebrüder Bornträger, Berlin-Stuttgart, $170 \mathrm{pp}$.

Hewitt G. \& Schroeter G. 1968: Population cytology of the genus Oedaleonotus. I. The karyotypic facies of Oedaleonotus enigma. Chromosoma 25: 121-140.

Imai H., Wada M., Hirai H., Matsuda Y. \& TsuchiKa K. 1999: Cytological, genetic and evolutionary functions of chiasmata based on chiasma graph analysis. J. Theor. Biol. 198: 239-257.
Lhano M., Adis J., Marques M. \& Battirola L. 2005: Cornops aquaticum (Orthoptera, Acrididae, Leptysminae): aceitação de plantas alimentares por ninfas vivendo em Eichornia azurea (Pontederiaceae) no Pantanal Norte, Brasil. Amazoniana 18: 397-404.

MAther K. 1938: Crossing-over. Biol. Rev. 13: 252-292.

Oberholzer I. \& Hill M. 2001: How safe is the grasshopper, Cornops aquaticum for release on water hyacinth in South Africa? In Julien M.H., Hill M.P., Centre T.D. \& Ding J. (eds): Biological and Integrated Control of Water Hyacinth, Eichhornia crassipes. Proceedings of the Second Global Working Group Meeting for the Biological and Integrated Control of Water Hyacinth No. 102. ACIAR, Canberra, pp. 82-88.

SeARLe J. 1993: Chromosomal hybrid zones in eutherian mammals. In Harrison R. (ed.): Hybrid Zones and the Evolutionary Process. Oxford University Press, New York, pp. 507-532.

Sym M. \& Roeder G. 1994: Crossover interference is abolished in the absence of a synaptonemal complex protein. Cell 79: 283-292.

WAdA M. \& IMAI H. 1995: Theoretical analyses of chiasmata using a novel chiasma graph method applied to Chinese hamsters, mice and dog. Jpn. J. Genet. 70: 233-265.

Received March 20, 2007; revised and accepted June 7, 2007 